\title{
МИРОВЫЕ ТЕНДЕНЦИИ КОНКУРЕНТНОЙ ПОЛИТИКИ, ИХ ОЦЕНКА
}

\author{
(c) 2020 Мамедова Айнур Эхтибаровна \\ аспирант кафедры экономической теории и экономического образования \\ РГПУ им. А. И. Герцена, Россия, Санкт-Петербург \\ E-mail:anna-ag@mail.ru
}

Мировой опыт показывает, что инвестиционное финансирование в каждой стране имеет свои особенности. Различия в структуре разных источников инвестиционного финансирования, в использовании разных методов инвестирования, объясняют как специфику политики, проводимой руководством отдельных учреждений, так и особенности государственного регулирования инвестиционной деятельности в конкретной стране. В данной статье будут рассмотрены мировые тенденции конкурентной политики, будет проведена их оценка.

Ключевые слова: конкурентная политика, глобализационные процессы, государственная поддержка, мировой опыт, малый и средний бизнес, пандемия коронавируса

Малый и средний бизнес является неотъемлемой частью государственной конкурентной политики как наиболее гибкой и динамичной формы деловой жизни. Бизнес является мобильным и пластичным для изменения условий коммерческого рынка, поэтому важно использовать его в конкурентной среде.

Исходя из последних методов организации МБ, важно отметить, что Правительство Российской Федерации постоянно работает над созданием благоприятных условий для развития МБ (см. рис. 1).
При формировании государственной конкурентной политики следует учитывать тот факт, что малые предприятия будут развиваться лучше, если будут созданы определенные условия (см. рис. 2).

С другой стороны, важно учитывать внешние факторы, влияющие на развитие предпринимательства. Конкурентоспособность малого бизнеса является основой для устойчивого развития стран с рыночной экономикой, хотя большой капитал определяет уровень их научного, технического и производственного потенциала.

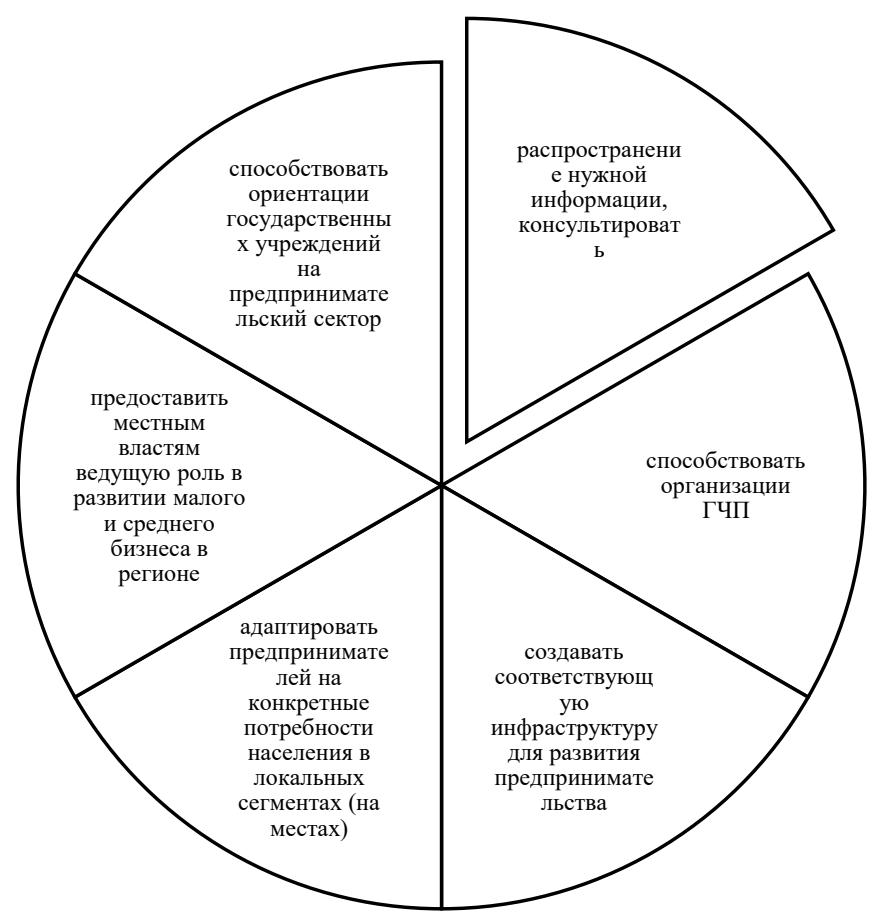

Рисунок 1. Задачи государственной политики по поддержке внутренней среды, благоприятствующей МБ в Российской Федерации 


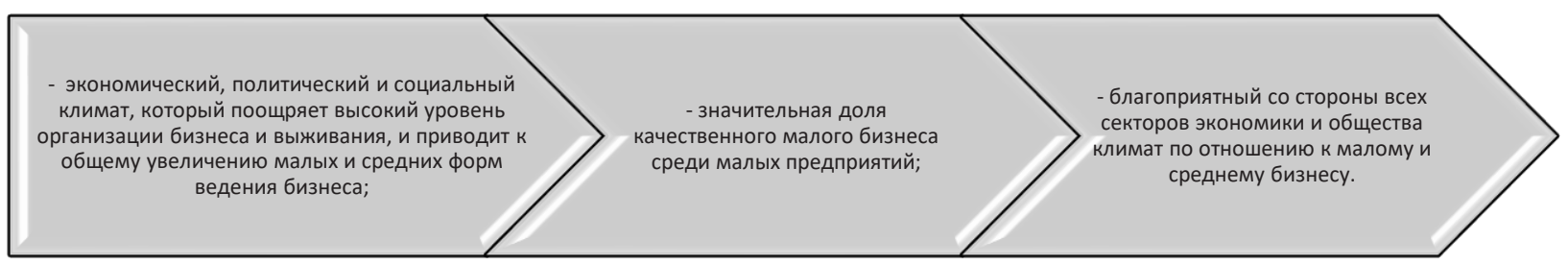

Рисунок 2. Необходимые условия для оптимального развития предприятий

В мировом сообществе под влиянием глобализационных процессов сформировалось два основных направления поддержки МСП:

1. Инвестиционно-инновационная поддержка на фоне реализации государственных программ финансирования проектов МСП.

2. Кризисная поддержка, которая в условиях пандемии Коронавируса в 2020 года стала новым направлением для всех стран мира.

Несмотря на то, что любая инновационная деятельность в определенном смысле является прогрессивным явлением, невозможно отрицать, с одной стороны, важность государственной поддержки и предоставления дополнительных стимулов, а, с другой, необходимость внесения регулирующих начал в развитие инновационной деятельности со стороны государства. Таким образом, необходимо, чтобы государство целенаправленно влияло на инновационный сектор малого бизнеса, в частности использовало в качестве инструмента правовое регулирование указанного сектора, поскольку развитие этой сферы является ключевым фактором для развития экономики в целом [1].

Зарубежный опыт убеждает в том, что у государства есть широкие возможности для регулирования инвестиционной деятельности с помощью институтов, а также макроэкономических и микроэкономических инструментов, что позволяет достичь целей экономического развития.

Следует отметить, что в зарубежной прак- тике существует широкий спектр форм регулирования научно-исследовательских и опытноконструкторских разработок и их связь с производством и потреблением. Причина этого не столько в разнообразии и спонтанности развития капиталистического производства, сколько в наборе требований, объективно существующих в процессе использования инноваций в различных обстоятельствах.

Для финансовой поддержки МСП в Соединенных Штатах были разработаны две программы [2] (см. рис. 3).

Сегодня ответственность за развитие предпринимательства установлена в ряде организаций, в том числе: Администрации малого бизнеса, Национальном научном фонде, Национальной сети центров внедрения новых технологий, Национальном исследовательском совете, Национальном институте стандартов и технологий, Национальной службе технической информации [3]. Они фокусируют свою деятельность на совершенствовании законодательства, оказании помощи предпринимателям в получении кредитов и гарантий для них. В рамках международных мероприятий выполняют функции программных подразделений, устанавливают сотрудничество по повышению уровня консультаций с новыми региональными консультативными и информационными центрами, а также оказывают помощь в разработке программ развития для МСП. Помимо местных центров кон-

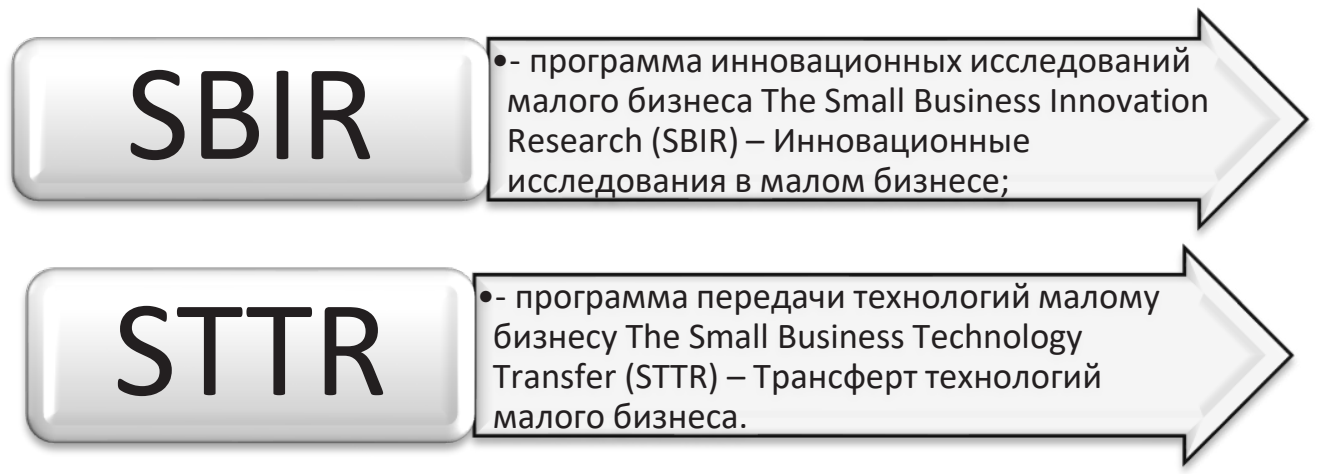

Рисунок 3. Программы поддержки МСП в США 
салтинга и информационных услуг, существуют также инновационные центры, которые являются «инкубаторами» для малого бизнеса, создавая новаторскую среду в инновационных сферах предпринимательства.

В Соединенных Штатах часть международной информационной сети была обновлена. Агентства по развитию малого бизнеса имеют доступ к ценной информации в Соединенных Штатах и даже в Европейском Союзе. Это также рынок малых и средних предприятий из менее развитых регионов или регионов, переживающих стагнацию [4].

Американская ассоциация развития науки и технологий работает в региональной среде, где местные органы власти активно сотрудничают в распространении инноваций среди МСП. В качестве основы для своей маркетинговой стратегии AARN разработал свое предложение услуг, «Global Temporary Technologies Presentation», которое состоит из четырех основных компонентов:

1) набор технологических предложений;

2) спектр технологических применений;

3) краткосрочные, среднесрочные и долгосрочные услуги;

4) маркетинговые исследования технологий.

Этот подход оказался эффективным в привлечении клиентов, о чем свидетельствует рост успешных контрактов только за последние пять лет (33\%) [5].

Программа маркетинговых исследований малого бизнеса направлена на привлечение инновационных возможностей малого бизнеса для решения научно-технических вопросов по теме ключевых федеральных министерств и национальных агентств. Каждое из этих учреждений может оказать поддержку в размере более чем 100 миллионов долларов США на исследования малых предприятий, количественно определить размер и виды финансовой поддержки потенциальных разработчиков, разработать тематические планы исследований, оценить перспективы предложений для малого бизнеса, провести конкурсы, в которых будут распределяться гранты, и контракты. Годовой бюджет программы исследований инновационного малого бизнеса позволяет за 2 миллиарда долларов США реализовать около 2000 инновационных проектов [6].

В Великобритании Министерство торговли и промышленности оказывает поддержку широкому кругу организаций и программ по развитию инноваций и применению результатов исследований в отрасли. Это сообщество Фарадея - объединение многих организаций и учреждений, включая научно-технические организации, университеты, профессиональные учреждения, торговые ассоциации и фонды.

Целью данных сообществ является создание своего рода маркетингового буфера, регулирующего взаимодействие науки, техники и бизнеса, а также передачу технологий для повышения конкурентоспособности промышленности Великобритании.

Среди крупнейших бизнес-организаций Шведская бизнес-ассоциация (Svenska Arbetsgivareföreningen) [7], в которую входят около 43000 компаний, организованных в 35 торговых ассоциациях, сообщество банковских организаций и Ассоциация предпринимателей газет.

Основной задачей SAF является участие в переговорах по коллективным договорам, а также предоставление услуг и консультаций по таким вопросам, как организация труда, участие работников в управлении, статистика заработной платы и защита работников. Если переговоры заходя в тупик, правительство может назначить промежуточный комитет.

Малый бизнес в Китае развивается очень успешно. Несколько лет назад правительство Китая решило перенаправить экономику страны с ресурсоемких предприятий на малые предприятия. По мнению китайских лидеров, базовая модернизация китайской экономики должна быть завершена в 2050 году, что сделает страну одним из лидеров по уровню экономического развития. Но результаты малого бизнеса в Китае можно увидеть уже сейчас - полки многих магазинов заполнены дешевыми товарами, которые производятся на малых предприятиях в Китае [8].

Национальная комиссия по развитию и реформам (NDRC) является основной движущей силой развития малого бизнеса в Китае, который начинает принимать необходимые правительственные решения, а также собирает статистическую информацию и данные о работе малых предприятий. На основании деятельности этого комитета принимаются решения по стимулированию определенных видов малого бизнеса в Китае [9]. Малые предприятия в Китае получают техническую помощь высокого уровня, а предприниматели имеют возможность получать необходимую информацию через специализированные веб-сайты и электронные библиоте- 
ки, а также участвовать в онлайн-семинарах или видеоконференциях, организуемых ведущими китайскими и международными экспертами по развитию малого бизнеса [10].

Накопленный мировой опыт управления инновационной деятельностью предприятий в странах с рыночной экономикой свидетельствует о значительных изменениях в этой сфере в последние десятилетия. С одной стороны, происходит обострение неценовой конкуренции на товары (прежде всего выявленные на уровне технического совершенства и качества продукции), особенно на мировых рынках, а с другой стороны, появляется стремление воспользоваться новыми торговыми возможностями, предоставляемыми современной государственной революцией, с ее достижениями Микроэлектроника и информационные технологии [11].

Анализ мировой практики показывает, что в современных условиях утвердились три модели участия государства в сфере конкурентной поддержки инновационных предприятий и их групп:

1. Реализация государственного контроля и активного вмешательства (Япония и Франция).

2. Учет рыночных тенденций и упор на бизнес-интересы (США, Великобритания).

3. Смешанный вариант (Россия) [12].

Говоря о прямых методах активного вмешательства, можно выделить три ключевых формы: административно-ведомственная, программноцелевая и инициативная, каждая из которых обладает определенными особенностями, которые определяются целью их создания условий функционирования [13].

В странах социализма, по сути, игнорировались объективные законы экономики вообще и законы инновационной деятельности, в частности. Их заменяли командно-административные методы управления экономикой, а конкурентную среду в экономике, которая чрезвычайно важна для научно-технического прогресса, пытались заменить системой социалистического соревнования [14].

Программно-целевая форма государственного регулирования инноваций наибольший эффект дает в тех направлениях научнотехнического развития, где прогнозируются научно-технические прорывы (в новых отраслях робототехники, биотехнологии).

Модель инициативы, которая особенно интенсивно развивается в Соединенных Штатах, является исключительно важным инструментом для ускорения научно-технического прогресса. Суть этой модели заключается в финансировании, предоставляемом индивидуальным изобретателям и малым предприятиям, которые созданы для разработки технических и других инноваций, а также научной, технической, консультативной и административной помощи [15].

Следует отметить, что политика интенсификации продажи товаров за счет мер по распространению продукции можно встретить в небольших компаниях в Российской Федерации. Отдельные местные учреждения позаботятся о том, чтобы определить потребности и удовлетворенность потребителей. Правда, последнее еще не стало массовым.

Однако в наше время местные хозяйствующие субъекты не отвечают этим требованиям. Задача состоит в том, чтобы сформулировать новые теоретические и практические рекомендации по управлению регуляторными компонентами. Анализ зарубежного опыта показал, что организационная и экономическая поддержка развития малого бизнеса играет ведущую роль в регуляторной политике любой страны мира. Использование специальных налоговых мер, в том числе налоговых льгот, помогает в инновациях и глобальных инвестициях. Их использование в той или иной группе позволяет правительству регулировать деятельность малых предприятий, устраняя нежелательные проблемы, связанные с их управлением.

Приоритетная роль отводится инновационным инструментам малого бизнеса Российской Федерации для политики продаж, изучения определенных аспектов потребительского спроса и структуры маркетинга. Повсюду в мире, наряду с классическим маркетинговым комплексом, основное внимание уделяется клиентам, используя различные методы координации и интеграции.

Суть современной концепции малого бизнеса состоит в том, чтобы определить детали индивидуальных запросов потребителей, обеспечить их лояльность, а также установить и поддерживать долгосрочные взаимовыгодные отношения с ними [16].

Управление небольшими предприятиями иностранных компаний основано на социальных и этических принципах с четкими критериями и просчитанными последствиями, нацеленными на повышение доступности товаров, 
доступности выбора, повышение осведомленности потребителей и улучшение качества их жизни. Кроме того, в современном мире внимание сосредоточено на социальных, экологических и политических проблемах, которые необходимо решать совместными усилиями всех членов общества.

С другой стороны, среда, в которой работают небольшие местные фирмы, усиливает конкуренцию и формирует институты гражданского общества, в то время как в странах с высоким уровнем глобализации в области экономического и социального развития создается и строится инновационное общество.

В развитых странах мира роль малого бизнеса сегодня превышает значимость продажи конкретного продукта и становится инструментом изменения экологических стандартов.

В контексте разработки рыночных принципов для малого бизнеса в Российской Федерации управление конкурентным потенциалом малым бизнесом как одна из важнейших современных бизнес-философий должно стать ключевым фактором обеспечения устойчивости предприятий. Однако, неспособность быстро реагировать на изменяющиеся рыночные условия и традиционный характер предпринимательского мышления является своего рода препятствием для эффективной предпринимательской деятельности местных субъектов малого бизнеса.

Проблема России заключается в том, что с 2013 года, когда произошло резкое снижение индекса иностранных предприятий, их число еще не восстановилось. Поэтому сегодня существует острая необходимость в разработке четкой стратегии и механизмов развития экономики страны в целом и инноваций, в частности, необходимых для определения возможностей внедрения инноваций.

Опыт промышленно развитых стран свидетельствует о конкретной проблеме, в которой некоторые аспекты данного опыта могут быть использованы в Российской Федерации.

Из приведенных выше теоретических и аналитических этапов исследования ясно, что в Российской Федерации нет единого подхода к определению механизмов поддержки малого бизнеса как основы реализации конкурентной политики государства. Как упоминалось ранее, инновации не являются прямым признаком небольшой компании. Зарубежная статистика использует только одни показатель - количе- ство людей, занятых в секторе малого бизнеса. Преимуществами этого стандарта являются: сопоставимый индекс стран по месту и времени, численность работников, которая указывает на возможности предприятия. Недостатком этого показателя является то, что количество людей, занятых в разных отраслях, не позволяет проводить сравнения на основе различий в производительности труда. Согласно официальным данным, в странах с развитой рыночной экономикой почти половина работающего населения работает в сфере малого бизнеса.

Основным источником финансирования инноваций в Российской Федерации были частные средства предприятий. Это особенно относится к малому бизнесу, где финансирование инноваций является более сложным. Показатели «Global Innovation Index» в 2016 году составили 61,40 в Соединенных Штатах Америки (четвертое место в мире), а в России - только 38,50 (43 место), что свидетельствует о сокращении числа компаний, активно внедряющих инновации [17].

По мнению экспертов, опыт других стран, активно использующих механизмы финансирования для генерирования средств финансирования инновационных проектов, может быть полезным для Российской Федерации [18].

В рамках краткосрочной реализации приоритетных областей необходимо создать ассоциации заинтересованных организаций и учреждений, а также повысить роль фундаментальных исследований для внебюджетных фондов и новых инновационных структур для поддержки финансовых исследований и разработок. В то же время необходимо улучшить взаимодействие между органами государственного управления и научными органами, техническими организациями, строить их отношения в основном, на основе конкурсного контракта или стандартного отбора проектов: государство должно предоставлять ученым возможность участвовать в совместных предприятиях с иностранными учеными. При описании локальной модели поддержки инноваций необходимо подчеркнуть, что зарубежная модель не может применяться в чистом виде. Каждая страна имеет свои особенности для формирования инновационной среды. Соответственно, отдельные инструменты инновационной политики и механизмы их использования, которые эффективны в одной стране, могут стать неэффективными в других странах. Поэтому, как правило, большинство государств 
осуществляют государственную инновационную политику и сочетают прямые и косвенные методы воздействия, уровень которых зависит от направления, в котором применяется их национальная инновационная политика.

Не смотря на сформированность механизмов поддержки развития МСП в различных государствах, в первом полугодии 2020 года финансирование в инновации и проекты малого и среднего бизнеса во всех странах мира приостановлены из-за мировой пандемии. На данный момент действуют кризисные схемы поддержки предпринимателей, так именно малый и средний бизнес оказались под угрозой банкротства в связи с полной или частичной приостановкой своей деятельности.
Только в европейских странах действует информационная поддержка по программам помощи европейскому бизнесу, пострадавшему от коронавируса. Принятые меры призваны решить такие проблемы, как нехватка наличных средств, неспособность погасить долги и вынужденное бездействие персонала.

Вместе с людьми, которых власти призывают остаться дома, на карантин уходят целые отрасли экономики. Что касается России, то с 28 марта по 30 апреля на каникулы с сохранением заработной платы перешла вся страна - что опять же негативно отразится на бизнесе.

Инфографика госпомощи различных стран своей экономике в период борьбы с распространением коронавируса показывает, что больше

\section{Таблица 1. Меры поддержки стартапов МСП в европейских странах в условиях коронавируса}

\begin{tabular}{|c|c|c|}
\hline Страна & Основной ресурс & Меры поддержки \\
\hline Франция & $\begin{array}{l}\text { Руководство по коронавирусу } \\
\text { от La French Tесh, агентства } \\
\text { по поддержке стартапов. }\end{array}$ & $\begin{array}{l}\text { Автоматическая отсрочка уплаты налогов и страховых взносов } \\
\text { за март. } \\
\text { Компании могут подать заявку на отсрочку уплаты налогов и } \\
\text { страховых взносов за последующие месяцы. } \\
\text { Кредит в инвестиционно банке Bріfrance, который поддержи- } \\
\text { вается государством, или обратиться туда за помощью, чтобы } \\
\text { Вріfranсе выступил в роли гаранта для получения кредита в } \\
\text { другом банке. } \\
\text { Президент Франции Эмманюэль Макрон заявил, что малые и } \\
\text { средние предприятия, попавшие в сложное положение, смогут } \\
\text { временно не платить за аренду, электричество, газ и воду. } \\
\text { Временные меры по предотвращению безработицы будут } \\
\text { распространены на все компании и позволят сократить рабо- } \\
\text { чие часы сотрудников, не увольняя их. Вкратце: если деятель- } \\
\text { ность вашей компании резко снизилась, вы можете сократить } \\
\text { количество рабочих часов сотрудников. При этом МсП должны } \\
\text { продолжать платить им большую часть зарплаты и могут за- } \\
\text { просить у государства возместить хотя бы часть этой суммы. }\end{array}$ \\
\hline Германия & $\begin{array}{l}\text { Руководство от немецкой } \\
\text { ассоциации стартапов } \\
\text { Bundesverband Deutsche } \\
\text { Startups. }\end{array}$ & $\begin{array}{l}\text { Все нуждающиеся в ликвидности компании смогут получить ее } \\
\text { в форме займов от государственного банка развития Kf W. } \\
\text { Компании могут попросить об отсрочке уплаты налогов. } \\
\text { Принят закон, расширяющий программу Kurzarbeit (работа } \\
\text { по сокращенному графику). Согласно ему, компании, которые } \\
\text { сокращают рабочие часы сотрудников, могут получить помощь } \\
\text { от государства. Это дает бизнесу альтернативу увольнениям. } \\
\text { Также предлагается изменить процедуру банкротства или по } \\
\text { крайней мере заморозить ее на несколько месяцев в интересах } \\
\text { компаний, вынужденных заявить о банкротстве. }\end{array}$ \\
\hline Италия & $\begin{array}{l}\text { Основной ресурс: } \\
\text { SOS-руководство от органи- } \\
\text { зации Italia StartUp }\end{array}$ & $\begin{array}{l}\text { Компании могут попросить об отсрочке уплаты налогов. } \\
\text { Стартапы с выручкой менее } 2 \text { млн. могут не платить налоги } \\
\text { вообще. } \\
\text { Ликвидность для малого и среднего бизнеса от государственно- } \\
\text { го кредитора Cassa Depositi e Prestiti Sp A. } \\
\text { Государственные гарантии на сумму до €5 млн. для малых и } \\
\text { средних предприятий. } \\
\text { Возможна заморозка платежей по ипотекам по соглашению с } \\
\text { банками. Самозанятые могут попросить свой банк отложить } \\
\text { или приостановить платежи по ипотеке или другим долгосроч- } \\
\text { ным кредитам. } \\
\text { Часть пакета по поддержке экономики будет направлена тем, } \\
\text { кто потерял работу, чтобы у них частично сохранился доход. }\end{array}$ \\
\hline
\end{tabular}




\begin{tabular}{|c|c|c|}
\hline Испания & $\begin{array}{l}\text { Раздел о коронавирусе на } \\
\text { сайте Barcelona Tech City. }\end{array}$ & $\begin{array}{l}\text { Возможность отсрочить налоговые платежи для малого и сред- } \\
\text { него бизнеса и самозанятых. } \\
\text { Отсрочка платежей по кредитам, выданным Генеральным се- } \\
\text { кретариатом промышленности. } \\
\text { Официальная кредитная организация Instituto de Credito Oficial } \\
\text { получила дополнительные ресурсы, чтобы выдавать кредиты } \\
\text { компаниям и фрилансерам в наиболее пострадавших секторах, } \\
\text { таких как туризм и транспорт. }\end{array}$ \\
\hline $\begin{array}{l}\text { Великобри- } \\
\text { тания }\end{array}$ & $\begin{array}{l}\text { государственный сайт для } \\
\text { малых предприятий, постра- } \\
\text { давших от коронавируса. }\end{array}$ & $\begin{array}{l}\text { Малые предприятия, которые не способны уплатить налоги, } \\
\text { могут подать заявку в Налоговую и таможенную службу об } \\
\text { отсрочке. На период эпидемии стандартная 3,5\%-ная комиссия } \\
\text { по отложенным налоговым платежам не взимается. } \\
\text { Государство готово выдавать кредиты компаниям, испытываю- } \\
\text { щим трудности из-за эпидемии. Ответственной организацией } \\
\text { в этой сфере будет государственный British Business Bank. } \\
\text { Небольшие компании смогут получить возмещение оплаты } \\
\text { больничного на срок } 14 \text { дней на каждого сотрудника (около } \\
\text { £200). Однако правительство предупредило, что компенсации, } \\
\text { возможно, придется ждать несколько месяцев, потому что ме- } \\
\text { ханизм еще не отлажен. } \\
\text { Самые маленькие компании во всех секторах экономики смо- } \\
\text { гут подать заявки на гранты на сумму до £10 тысяч. } \\
\text { Принят пакет помощи на сумму £20 млрд., в который войдут } \\
\text { налоговые каникулы и другие меры по защите бизнеса и граж- } \\
\text { дан от экономического коллапса.Эти меры могут быть приме- } \\
\text { нены и к стартапам. } \\
\text { Будут выдаваться кредиты для бизнеса с первоначальной } \\
\text { суммой гарантий в £330 млрд., или } 15 \% \text { ВВП страны. Граждане } \\
\text { могут получить трехмесячную отсрочку по ипотеке. }\end{array}$ \\
\hline Ирландия & $\begin{array}{l}\text { список источников информа- } \\
\text { ции от Scale Ireland - } \\
\text { некоммерческой организа- } \\
\text { ции, занимающейся под- } \\
\text { держкой ирландских старта- } \\
\text { пов. }\end{array}$ & $\begin{array}{l}\text { Налоговая служба может отсрочить налоговые платежи для } \\
\text { компаний, пострадавших от коронавируса. } \\
\text { Возможно сокращение рабочих часов сотрудников. Планирует- } \\
\text { ся, что работодатели, которые выплачивают персоналу хотя бы } \\
\text { часть заработной платы, получат компенсацию от правитель- } \\
\text { ства. } \\
\text { Схема кредитных гарантий (Credit Guarantee Scheme), пред- } \\
\text { назначенная для кредитов на cумму до } 1 \text { млн. Заявку можно } \\
\text { подавать через AIB, Bank of Ireland и Ulster Bank. } \\
\text { Займы для микробизнеса через MicroFinance Ireland. } \\
\text { Стратегическая банковская корпорация Ирландии выдает за- } \\
\text { ймы на сумму до } 1,5 \text { млн. через свой фонд рабочего капитала } \\
\text { объемом €200 млн. } \\
\text { Пакеты по спасению и реструктуризации бизнеса от Еnterprise } \\
\text { Ireland для уязвимых, но дееспособных компаний, которые } \\
\text { нуждаются в трансформации бизнеса. } \\
\text { Фиксированные выплаты в размере €203 в неделю на протяже- } \\
\text { нии } 6 \text { недель для самозанятых, потерявших источник дохода, а } \\
\text { также для всех, кто потерял работу по вине коронавируса. } \\
\text { Гранты от Enterprise Ireland, IDA Ireland, Lосаl Enterprise Office } \\
\text { и Údarás na Gaeltachta для бизнеса с целью поддержки иннова- } \\
\text { ций, рыночной диверсификации, цепи поставок и конкуренто- } \\
\text { способности. }\end{array}$ \\
\hline Португалия & Rafael Marchante & $\begin{array}{l}\text { Продление дедлайнов по уплате налогов. } \\
\text { Кредитная линия на €200 млн. для обеспечения потребности } \\
\text { компаний в ликвидности. } \\
\text { Кредитная линия на €60 млн. для микробизнеса в сфере туриз- } \\
\text { ма. } \\
\text { Поддержка занятости: государство будет выплачивать большую } \\
\text { часть заработной платы сотрудников, даже если они не ходят } \\
\text { на работу, чтобы работодатели могли контролировать свои } \\
\text { расходы. } \\
\text { Специальный бюджет на профессиональное обучение людей, } \\
\text { потерявших работу. } \\
\text { Отсрочка уплаты налогов и взносов для самозанятых. }\end{array}$ \\
\hline
\end{tabular}




\begin{tabular}{|c|c|c|}
\hline Швеция & $\begin{array}{l}\text { Список государственных мер, } \\
\text { опубликованный Министер- } \\
\text { ством финансов Швеции. }\end{array}$ & $\begin{array}{l}\text { Правительство берет на себя расходы по оплате больничных на } \\
\text { два месяца. } \\
\text { Компании могут отсрочить уплату страховых взносов, налога } \\
\text { на заработную плату и НДС на срок до } 12 \text { месяцев. Компании, } \\
\text { которые уже уплатили налоги за первую половину } 2020 \text { года, } \\
\text { могут получить эту сумму назад от Налоговой службы Швеции. } \\
\text { В зависимости от каждой конкретной ситуации, правительство } \\
\text { возместит три четверти издержек от сокращения рабочих часов } \\
\text { и временного бездействия персонала, чтобы компании могли } \\
\text { избежать увольнений. } \\
\text { Центральный банк (Riksbank) готов выдавать займы банкам } \\
\text { на общую сумму до } 500 \text { млн. крон, чтобы поддержать систему } \\
\text { кредитования в стране. }\end{array}$ \\
\hline Дания & $\begin{array}{l}\text { Copenhagen Capacity - } \\
\text { организация по поддержке } \\
\text { бизнеса в Копенгагене - } \\
\text { принимает вопросы от пред- } \\
\text { принимателей. }\end{array}$ & $\begin{array}{l}\text { В случае заболевания сотрудника работодатель получает ком- } \\
\text { пенсацию выплаченной заработной платы и больничного. } \\
\text { Компании могут временно сократить рабочие часы персонала } \\
\text { и получить частичную компенсацию по выплате зарплаты при } \\
\text { условии, что не будут увольнять сотрудников. Сотрудники мо- } \\
\text { гут рассчитывать на дополнительное пособие по безработице. } \\
\text { Особый бюджет на случай потенциальных массовых увольне-- } \\
\text { ний. }\end{array}$ \\
\hline Финляндия & $\begin{array}{l}\text { Список мер, принятых } \\
\text { Банком Финляндии. }\end{array}$ & $\begin{array}{l}\text { Информация и советы по поводу эпидемии на сайте финского } \\
\text { правительства. }\end{array}$ \\
\hline Австрия & Austrian Economic Chambers. & $\begin{array}{l}\text { Отсрочка налоговых платежей. } \\
\text { Специальные кредиты для компаний в сфере туризма. } \\
\text { Прямые кредиты пострадавшим предприятиям. }\end{array}$ \\
\hline Нидерланды & $\begin{array}{l}\text { Торговая плата Нидерлан- } \\
\text { дов опубликовала FAQ для } \\
\text { предпринимателей, а также } \\
\text { дорожную карту для компа- } \\
\text { ний }\end{array}$ & $\begin{array}{l}\text { Компенсация расходов на заработную плату. Бизнес получит } \\
\text { субсидирования, если ни один из сотрудников не будет уволен } \\
\text { по экономическим причинам. } \\
\text { Самозанятые лица могут получать дополнительную пособие в } \\
\text { течение трех месяцев по ускоренной процедуре. } \\
\text { Отсрочки уплаты налога и уменьшение штрафов. } \\
\text { Предприятия, которым тяжело получить кредит, могут ис- } \\
\text { пользовать схему гарантированного финансирования бизнеса. } \\
\text { Правительство предлагает увеличить потолок гарантии с } 400 \\
\text { млн. до €1,5 млрд. } \\
\text { Туристическая индустрия, возможно, получит компенсацию } \\
\text { убытков, связанных с коронавирусом. Сейчас это распоряжение } \\
\text { разрабатывается и срочно передается в Европейскую комиссию } \\
\text { для оценки допустимой государственной помощи. }\end{array}$ \\
\hline
\end{tabular}

всего средств из госбюджета для борьбы с вирусной инфекцией выделяют США - более \$2 трлн., что составляет $12,4 \%$ от ВВП. При этом на территории страны выявлено свыше 360 тыс. зараженных.

Более \$ 1 трлн. выделяет правительство Германии, где зафиксировано 104 тыс. заболевших коронавирусом. По 20\% от ВВП составляет госпомощь экономике в Японии и Италии, при чем в европейской стране в 33 раза больше подтвержденных случаев инфицирования.

В России правительство выделяет из федерального бюджета \$ 20 млрд. для поддержки экономики в период пандемии, что составляет 1,2\% от ВВП. 3 апреля президент России Владимир Путин подписал закон о кредитных каникулах для граждан, индивидуальных предпринимателей, малых и средних предприятий, оказавших- ся в тяжелой ситуации из-за коронавируса.

Итак, глобальное события оказывают очень сильное влияние на экономики стран. Правительства этих стран, в свою очередь, обязаны предпринимать меры по оказанию поддержки экономикам своих государств, только вот в каждой стране поддержка разная.

Итак, пандемия коронавируса заставила многие правительства ввести карантин, ограничить работу компаний и организаций. Одна из самых пострадавших отраслей - малый и средний бизнес (МСБ), на котором в значительной степени держится экономика многих стран. Лишь небольшое число таких фирм может протянуть без заработка до конца ограничительных мер, к тому же неизвестно, сколько времени уйдет на восстановление после того, как они будут сняты. 


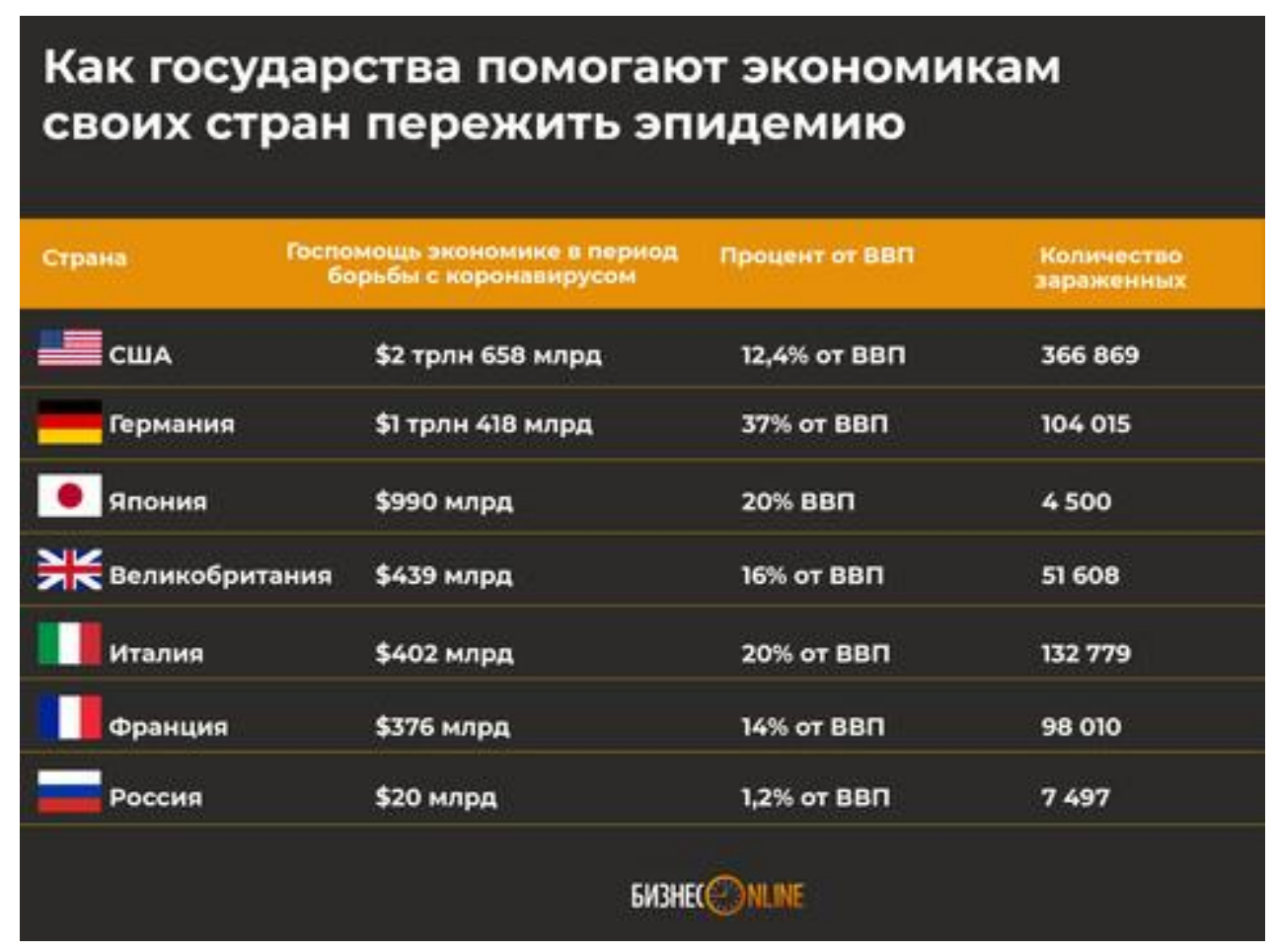

Рисунок 4. Кризисные фонды стран мира в борьбе с коронавирусом 2020 года

Уже сейчас, до снятия карантина весь крупный, средний и малый бизнес начинает разрабатывать программу стратегии перехода к работе в новых условиях, направленную на поиск равновесия между поддержкой бизнеса, находящегося на грани банкротства и поддержкой населения, оказавшегося в тяжелейших условиях. В связи с этим остро возникла задача пересмотра существующей модели регулирования конкуренции в условиях пандемии.

\section{Библиографический список}

1. Щербаков В. Управленческие решения и экономический рост/ В. Щербаков // Проблемы теории и практики управления - 2012, - № 5 - C. 17

2. Bo Zhao, Rosemarie Ziedonis. State governments as financiers of technology startups: Evidence from Michigan's R\&D loan program // Research Policy. - № 49, Issue 4May 2020. Article 103926

3. DOE funding for latest SBIR Phase I projects // Focus on CatalystsVolume 2019, Issue 9. - September 2019._- P. 6-7

4. Albert N.Link, John T.Scott Government as entrepreneur: Evaluating the commercialization success of SBIR projects // Research Policy. - 39, Issue 5 June 2010. - P. 589-601.

5. «U.S. Economic Development Administration: Fiscal Year 2015 Annual Report» (PDF). Eda.gov. (дата обращения: 05.05.2020)

6. Yong Suk Lee. Government guaranteed small business loans and regional growth // Journal of Business VenturingVolume 33, Issue 1January 2018. - P. 70-83.

7. Svenska Arbetsgivareföreningen (Association of Swedish Employers). http:// SAF.se (дата обращения: 05.05.2020)

8. Yu Cui, Chuan Sun, Hongjun Xiao, Chunming Zhao. How to become an excellent entrepreneur: The moderating effect of risk propensity on alertness to business ideas and entrepreneurial capabilities // Technological Forecasting and Social ChangeVolume 112November 2016. - P. 171-177.

9. Jin Yang, Jian Huang, Yanhua Deng, Massimo Bordignon. The rise of red private entrepreneurs in China: Policy shift, institutional settings and political connection // China Economic Review. - Volume 61 June 2020. -Article 101431

10. Мусостова Д. Ш., Бисаева Д. И. Государственная поддержка малого и среднего бизнеса в Китае // Экономика и менеджмент инновационных технологий. - 2016. - № 1 (52). - С. 94-97. 
11. Овчаренко Т. С. Мировой опыт организации и управления инновационно-инвестиционной деятельностью предприятий / Т. С. Овчаренко // Формирование рыночных отношений: Сборник научных трудов.Вип.116. 2017.- С. 93

12. Инновационный менеджмент: Справ. пособие. / Под ред. Завалина П.Н., Казанцева А. К.- М.: Центр исследований и статистики науки, 2008.- С. 318

13. Береговой В.В. Теория и методология финансирования инноваций в условиях глобализации мировой экономики: диссертация ... доктора экономических наук: 08.00.10 / Береговой Владимир Александрович; [Место защиты: ГОУВПО «Санкт-Петербургский государственный инженерно-экономический университет»].-Санкт-Петербург, 2008.-С. 18

14. Инновационная динамика: глобальные тенденции и перспективы Беларуси / Н.И Богдан - Минск: УП «Энциклопедикс», 2012.-С. 62

15. Черванев Д. М. Структурно-технологические факторы и инновационные процессы в моделях экономического развития // Вестн. Киев. ун-та. Экономика.-2017.- Вып. 36.- С. 46

16. Алексунин, В.А. Маркетинг: Учебник // В.А. Алексунин.-6-е изд.- М.: Издательско-торговая корпорация «Дашков и $\mathrm{K}^{\circ} »:$ 2016.- С. 77

17. Global Innovation Index 2016 rankings // globalinnovationindex.org. - [Электронный ресурс].- Режим доступа к pecypcy: https://www.globalinnovationindex.org/Home (дата обращения: 04.05.2020)

18. Меркушева, А.Е. Анализ мирового опыта поддержки инновационной деятельности / А. Е. Меркушева // Молодой ученый.-2017.- № 5 (139).-С. 203 